--Raf. J. Sci.,Vol.27,No.4 / Special Issue for the Third Scientific Conference of Biology,pp.114-127,2018 --

\title{
Colon Cancer Early Detection by some Serum's Antigenic, Enzymatic and Free- Serum's DNA Indicators
}

\author{
*Noor A. Azeez \\ ** Sarab D. Sulayman \\ *** Iman Adel \\ *Department of Chemistry/ College of Science / University of Mosul \\ ** Department of Biology/ College of Science / University of Mosul \\ ***Department of Chemistry/ College of Science / University of Mosul
}

(Received $30 / 9$ / 2018; Accepted 1/11/2018)

\begin{abstract}
This research include (104) patient's blood serum diagnosed with colon cancer proved by colonoscopy and histopathology. Blood samples had been selected consecutively over the period March 2013 to April 2014 from patients treated in Oncology and Nuclear Medicine hospital, AlJumhory hospital/Mosul and azadi Teaching Hospital/Kirkuk. All cases and controls were aged (2185-years). One hundred normal blood donor individuals had been used as controls. Antigenic tumor markers which include carcino-embryonic antigen (CEA) and Carbohydrate antigen 19-9 (CA 19-9) had been measured in blood's serum from 104 patients with colon cancer. Results indicate a significant elevation $(\mathrm{p}<0.05)$ in levels of CEA and C19-9 only in patients with advanced stage $\mathrm{C}$ and metastatic stage D compared with control. Beside biochemical enzymatic tumor markers that included Cyclooxygenase, Arginase showed significantly increase $(\mathrm{p}<0.05)$ of enzymatic activity for colon cancer patients with early stage (A) compared with controls. While the serum alkaline sphingomyelinase level was significantly decreased $(\mathrm{p}<0.05)$ in colon cancer patients in stage A compared with controls and this decrease was independent of Dukes' stage, thus strengthening the hypothesized validity of these assays to be used as serum test for the early detection of colonic neoplasia. The results of this research also revealed a significant increase $(p<0.05)$ in the serum's free DNA in all stages of colon cancer patient's compared with control grope for this it was considered as a good indicator of early detection of colon cancer.
\end{abstract}

Keywords: Sphingomyelinase, Cyclooxygenase, Arginase, Free-cell DNA, Colon cancer.

\section{التشخيص المبكر لسرطان القولون بواسطة بعض المؤشرات المستضدية والانزيمية والدنا الحرفي السيرم}

$$
\begin{aligned}
& \text { الملخص } \\
& \text { تضمن البحث أخذ } 104 \text { عينة سيرم لام مرضى مصابين بسرطان القولون نم تشخيص حالتهم مجهريا ونسيجيا حيث اخذت هذه } \\
& \text { العينـات للفترة مـن الثـهر الثالث } 2013 \text { الـى الثـهر التاســع } 2014 \text { مـن المرضـى المـراجعين لمستتـفى الطـب النـووي، المستشـفى } \\
& \text { الجمهوري، ومسنتفى آزادي التعليمي بكركوك، كما اخذت } 100 \text { عينة دم لاثخاص اصحاء اعتبرو كمجوعة سيطرة. حميع العينات } \\
& \text { للمرضسى والاصحاء كانت اعمارهم تتراوح بين 21-85 سنة. تم اجراء اختبارات مؤشرات الورم لمستضدي CEA والـ C19-9 في } \\
& \text { مصل الدم للمرضى في المراحل المختلفة لسرطان القولون اضافة الى مصل دم الاشخاص الاصحاء. واظهرت النتائج ارتفاعا معنويا } \\
& \text { لهذين المستضدين عند مستوى احتمالية (P>0.05) فقط في المرضى الذين يعانون من مرحلة متقدمة C والمرحلة المنتشرة D مقارنة } \\
& \text { بمجموعة السيطرة. كما نم اجراء اختبارات قياسات مؤشرات الورم الانزيمية حيث اظهرت النتائج ان المرضى الذين يعانون من مرحلة }
\end{aligned}
$$


مبكرة A من المرض اظهرت زيادة معنوية (P<0.05) في الفعالية الانزيمية لكل من سايكلواوكسجينيز Cycloxygenase وارجنيز

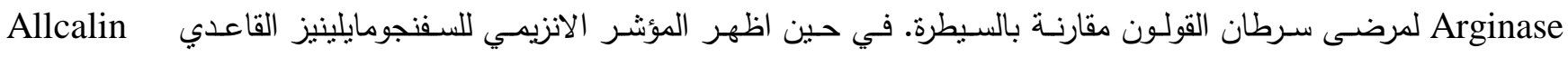
انخفاضـا معنويـا في مرضى سـرطان القولون في المرحلة المبكرة A مقارنـة مـع مجموعة السبطرة. مما يؤكد

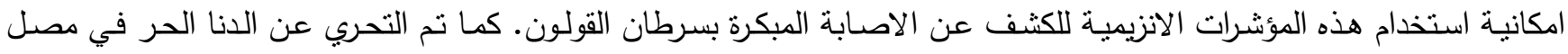
المرضى والاصحاء واظهرت نتاءج البحث زيادة معنوية عند مستوى الاحتمالية (P > 0.05) في مصل دم المصابين بالمرض في

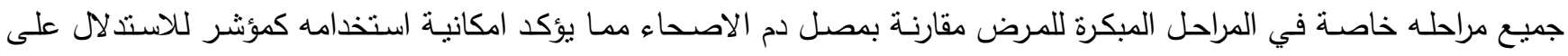
المراحل المبكرة للاصابة بسرطان القولون. الكلمات الدالة: سفنجومايلينيز ، سايكلواوكسي جنيز ، ارجنينيز ، الدنا الحر، سرطان القولون.

\section{INTRODUCTION}

Colorectal cancer is the second most common cause of cancer related death in western countries after lung cancer in men and breast cancer in women (Mihajlovic-Bozic, 2004). Colorectal cancer can be classified by a system called Dukes' staging ranging from stage A to stage D. The Dukes' stage describes the extent of invasion or spread of a tumor and correlates with overall survival, i.e. patients have an $83 \%$ survival chance with a Dukes stage A tumor versus 3\% chance of survival if diagnosed with Dukes' stage D (Campbell et al., 2001; Brünner et al., 2006). There were a lot of markers for colon cancer detection in body fluids, such as antigenic tumor markers that utilized in cancer detection, such as carcino embryonic antigen CEA, and CA 19-9. CEA was also present in certain healthy tissues, although concentrations in tumors were on average 60-fold higher than in the nonmalignant tissues (AlSaadi et al., 2014). High CEA levels are specifically associated with colorectal cancer CRC progression, and increased levels of the marker are expected to fall following CRC surgery (Duffy, 2001). However, even in the absence of cancer, high CEA levels may also occur in response to inflammatory conditions, such as hepatitis, inflammatory bowel disease (IBD), and pancreatitis. Thus, CEA does not provide sufficient sensitivity and reliability for the early detection of CRC. Another antigenic tumor marker CA 19-9 is synthesized by normal human pancreatic and biliary duct cells and by gastric, colon, endometrial, and salivary Epithelia (Pavai and Yap 2003). In serum, it exists as a mucin with high molecular mass (200 to $1000 \mathrm{kDa}$ ) glycoprotein complex, Elevations in CA 19-9 level correlate with the degree of tumor differentiation as well as the extent of tumor mass (Abdallah et al., 2013).

The pattern of enzymatic alterations may be linked with the malignant state and the progression of cancerous cells in the tumor. Differences in the activities or concentration of certain enzymes between cancer cells and their normal counterparts might be useful as biological markers of malignancy in particular tumors (Jamshidzadeh et al., 2001) such as alkaline sphingomyelinase alkSMase EC. number 3.1.4.12 present in the intestinal tract and additionally human bile. It hydrolyses sphingomyelin in both intestinal lumen and the mucosal membrane in a specific bile salt dependent manner. Several isoforms of alk-SMases have been identified and classified by their $\mathrm{pH}$ optima: alkSMase has been located specifically to the intestinal tract, where high levels are found in the small intestine and lower in the colon with a gradual decline towards rectum

The enzyme is of specific properties, such as bile salt dependency, high stability, and tissue specific expression (Cheng et al., 2002; Wu et al., 2004). In the colon, the enzyme may play antiproliferative and anti-inflammatory roles through generating ceramide (Duan et al., 2007; WU et al., 2006). 


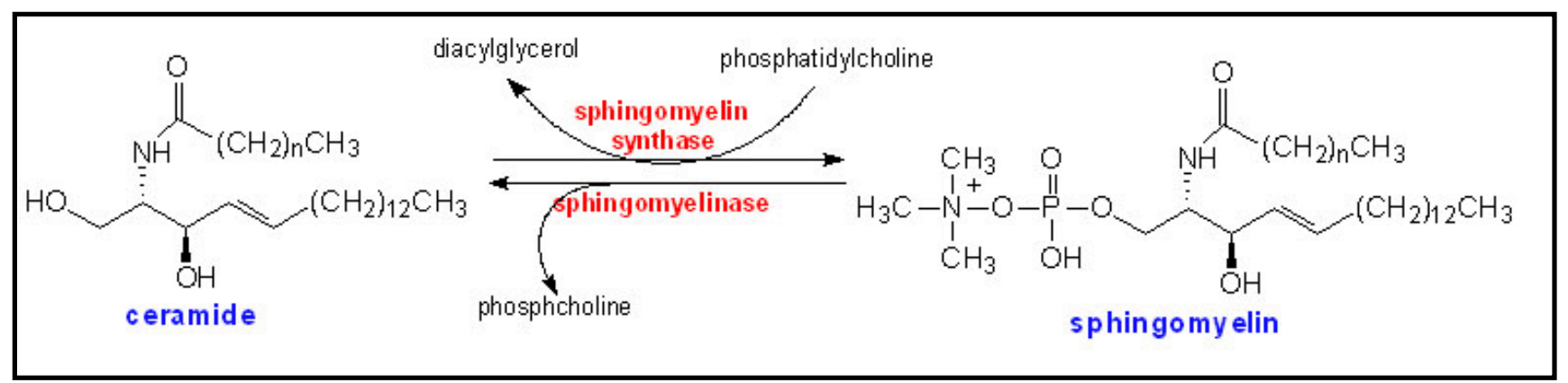

Fig. 1: Sphingomyelin is cleaved by sphingomyelinase to create phosphochoine and ceramide as products.

Human Cyclooxygenase-2 (COX-2) (EC 1.14.99.1) COX-1 and COX-2 are the two isoforms of cyclooxygenase, which convert arachidonic acid (AA) into several eicosanoids such as prostaglandin, thromboxanes and prostacyclin, which participate in several normal physiologic processes and inflammation (Urade, 2008). Over expression of COX-2 has been reported in a variety of cancers, including those arising in the colon, stomach, breast, lung, esophagus, pancreas, urinary bladder, prostate and head and neck (Urade, 2008).

Arginase, (L-arginine amidino hydrolase, EC 3. 5. 3. 1. Due to the importance of arginase enzyme in different malignant disorders Arginase is homo trimeric binuclear manganese metalloenzyme that catalyzes the hydrolysis of L-arginine, rendering urea for ammonia elimination, mainly in ureotelic animals, and L-ornithine (a non-protein amino acid) for biosynthetic pathways. There are at least two forms of arginase. Arginase 1 cytosolic and is most abundant in the liver, primarily responsible for ammonia detoxification as urea (Mahmoud et al., 2009). A second isoenzyme, arginase II, is involved in the production of ornithine as a precursor to proline, glutamate or polyamines, essential for cellular growth (Ash, 2004).

The use of DNA as a biomarker in clinical medicine for early diagnosis, has been a significant advancement in the field (Elshimali et al., 2013). Whether the DNA is present in normal locations such as the nucleus and mitochondria or circulating free in the blood and body fluids, we utilized cell-free DNA cfDNA as a valuable biomarker for early diagnosis in colon cancer.

The early detection of colon cancer is an important factor in reducing colon-cancer mortality, So that the aims of this study is to find several biochemical tumor markers such as Antigenic, enzymatic and free-Serum's DNA that have been tested to support tumor differential diagnosis and may provide a valuable tool for the screening and early detection of colorectal cancer.

\section{MATERIALS AND METHODS}

This study include (104) patients diagnosed with colon cancer and proved by colonoscopy and histopathological examination of biopsy.

Sample selected consecutively over the period March 2013 to April 2014 from the patients treated in Mosul Oncology and Nuclear Medicine Hospital, Jumhory Hospital/ Mosul and, Azadi Teaching Hospital/Kirkuk.

Clinical diagnosis in each case was established according to the oncologist. The complete clinical and personal history of the patient control was recorded. All cases and controls were aged (21-85years). The patients in the study were clinically and histologically diagnosed as a newly (stage A and B), advanced (stage C) and metastasis (stage D) colon cancer patient, and free from other chronic 
diseases such as diabetes, hypertension, or other cardiac, liver and renal disease. Female cases were not pregnant or lactating, beside one hundred normal blood donor individuals had been used as controls that were free from cancer or chronic diseases. All patients and controls gave informed, written consent for participation. Serum from these patients obtained before surgery. Beside 24 samples of each tumor and normal tissue had been taken from 12 colon cancer patients in different Dukes stages (A, B, C and D) then kept in deep freeze for molecular studies.

\section{Blood sample collection}

Ten milliliters of venous blood was taken from each patient and left for (15) minutes at room temperature for coagulation, then serum were separated by centrifugation at (3000 xg)for 10 minutes, and divided in aliquot and kept frozen at $\left(-20 \mathrm{C}^{\circ}\right)$ for the enzymatic assays, biochemical tests and $200 \mu \mathrm{L}$ of serum taken immediately for free DNA extraction. Antigenic tumor markers determination. Carcino-Embryonic Antigen (CEA). CEA level was assayed using ELFA technique (Enzyme Linked Fluorescent Assay) for quantitative measurement of CEA on miniVIDAS instruments using serum specimens. Principle. The assay principle is a two-step immunoassay sandwich method measuring a fluorescent signal. A solid-phase receptacle (SPR) serves as solid support to which anti-CEA monoclonal antibody (derived from mouse) is coated. Serum specimen, calibrator, or control samples are incubated in the SPR to allow capture of bound material to the solid phase. Unbound components are washed away during a washing step. Alkaline-phosphatase labeled anti-CEA polyclonal antibody (goat derived) is added and incubation begun. During incubation labeled anti CEA binds to solid-phase captured CEA. Unbound material is washed away during a second wash step. The substrate (4-methylumbelliferyl phosphate is added to the SPR and cycled in and out. During this incubation the enzyme catalyzes a reaction in which a fluorescent product is produced (4-methyl-umbelliferone) and measured at $450 \mathrm{~nm}$ by the mini VIDAS analyzer. The intensity of fluorescence is proportional to the concentration of CEA present in the sample. Fluorescence intensity is converted to a concentration by comparison with a signal generated by known concentrations of CEA in calibrators. The final concentration is printed by the analyzer.

\section{Carbohydrate Antigen 19-9 (CA19-9)}

CA19-9 level was assayed using ELFA technique (Enzyme Linked Fluorescent Assay) for quantitative measurement of CA19-9 on miniVIDAS instruments using serum specimens.

\section{Estimation the activity of some marker enzymes in serum of colon cancer patients Human Alkaline Sphingomyelinase}

Serum Alkaline Sphingomyelinase was determined by using kit assayed according to the manufactured procedure (Cusabio Biotech, Cat. No.MBS039905, USA). (Hertervig et al., 1997),

\section{Principle}

Quantitative sandwich enzyme immunoassay technique had been used in this study. Antibody specific for ALK-SMASE has been precoated into solid phase ELISA microtiter wells, ALK-SMASE as antigen samples. 


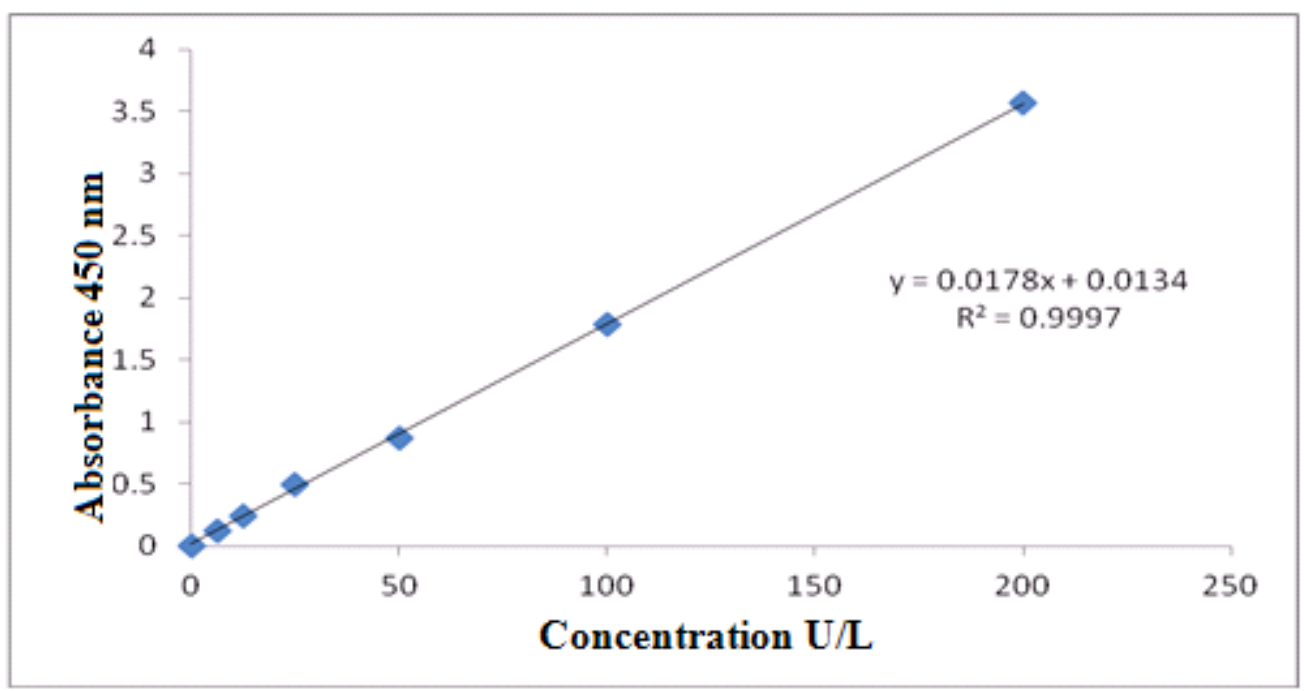

Fig. 2: ALK-SMASE standard curve.

Human Cyclooxygenase-2 (COX-2) (EC1.14.99.1)

COX-2 was determined by using kit assayed according to the manufactured procedure (Biosource, Cat. No. MBS164164, USA) (Singh et al., 2011).

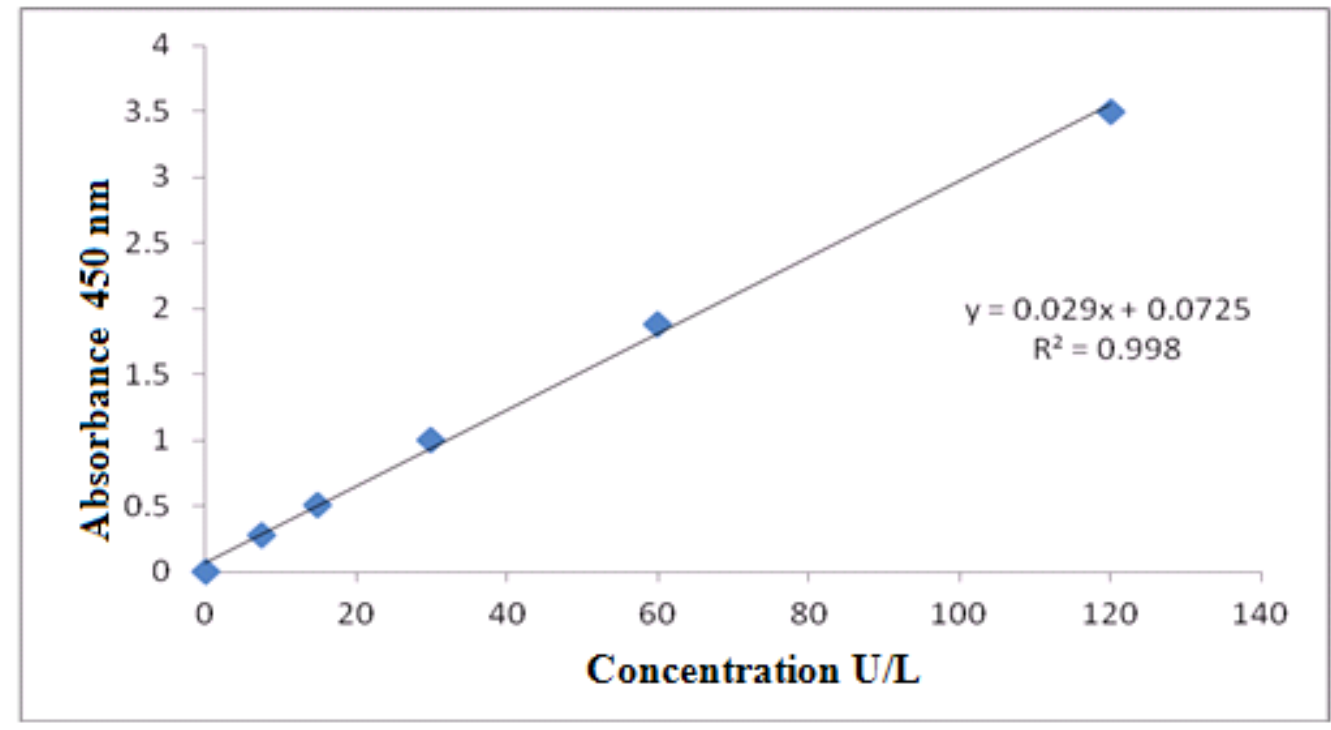

Fig. 3: Human Cyclooxygenase-2 standard curve.

\section{Arginase, L-arginine amidinohydrolase, EC3. 5. 3. 1.}

The enzyme activity was determined according to (kocna et al., 1996) procedure. Arginase, (Larginineamidinohydrolase, EC3.5.3.1) converts L-arginine in to L-ornithine and urea. The elevated activity of arginase has been reported in serum as well as in colorectal, gastric and mammary carcinoma tissues. Arginase activity in the serum is determined by a two-step method. The concentration of ornithine (as a product of the first reaction) is measured by a colorimetric method. 


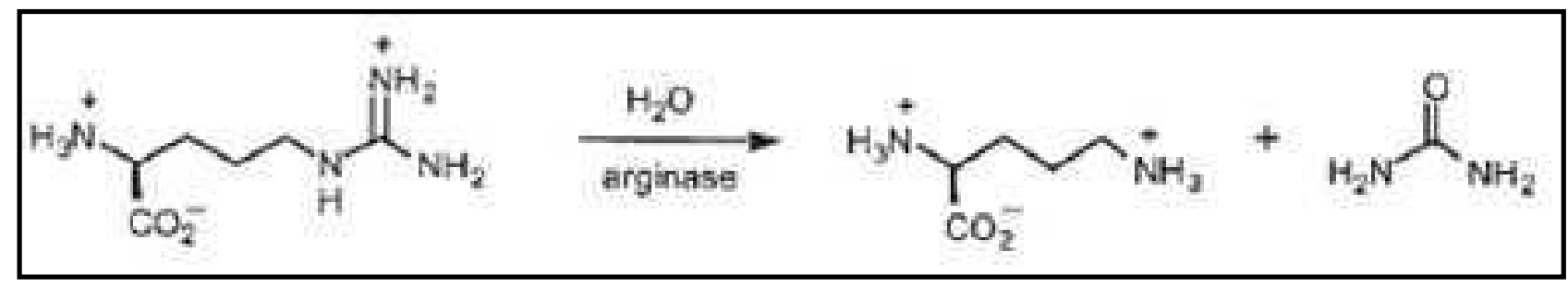

Fig. 4: The arginase reaction (David E. Ash, 2004).

Reaction conditions consist: $500 \mu$ ï of assay solutions $(35 \mathrm{mmol} / 1$ Tris-HCl buffer $\mathrm{pH} 9.5-20$, arginine 0.348, $0.009 \mathrm{gm} \mathrm{MnCl2}$ ), $25 \mu$ ï of serum, $25 \mu$ ï of $5 \mathrm{mmol} / 1$ Tris- $\mathrm{HCl}$ buffer. The incubation of samples was carried out in a water-bath at $37{ }^{\circ} \mathrm{C}$ for 120 minutes and stopped by immersing tubes in a boiling water-bath for 5 minutes concentration was determined by an end-point ninhydrin. Ninhydrin reagent $(0.5 \mathrm{ml})$ and acetic acid $(1.5 \mathrm{ml})$ were added to the incubation medium reaction carried out in a boiling water bath for 60 minutes. This reaction was stopped by cooling to room-temperature and the colored reaction product was evaluated by using a spectrophotometer at $515 \mathrm{~nm}$ in a $1 \mathrm{~cm}$ glass cuvette ornithine concentration was calculated from calibration standards curve as shown in figure.

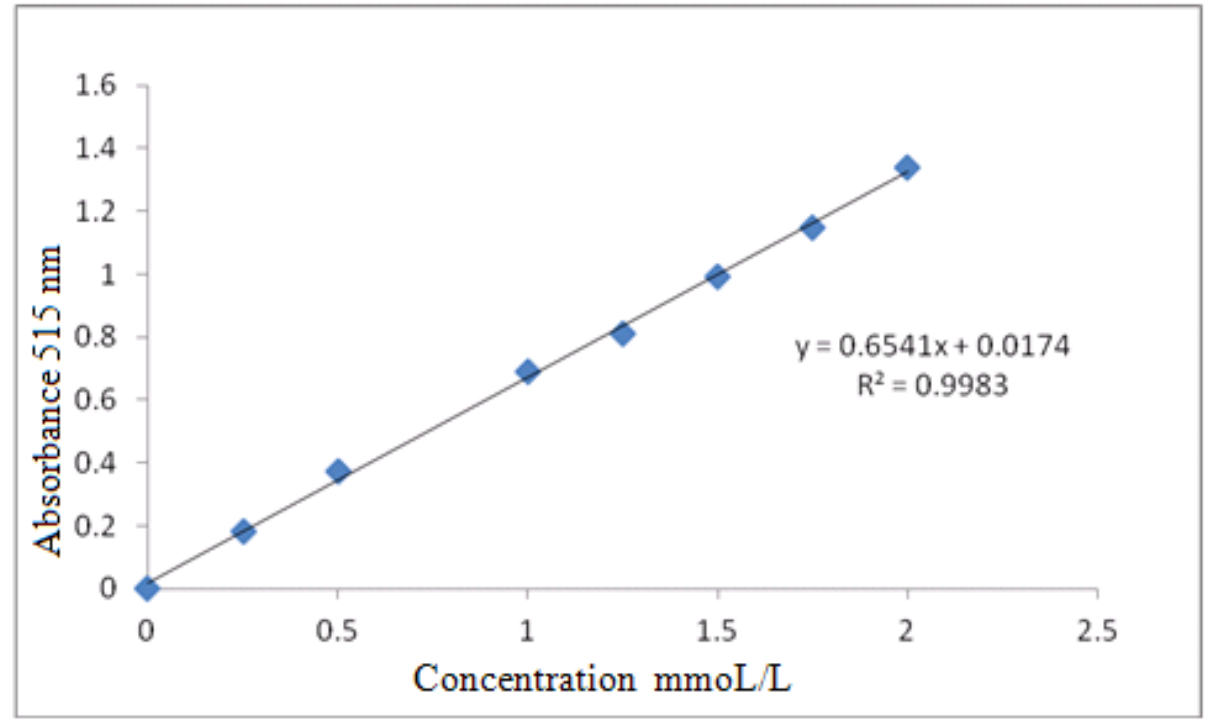

Fig. 5: Ornithine - standard curve

\section{Free serum's DNA isolation}

In various pathologic conditions, qualitative and quantitative changes in circulating DNA have been shown. Only small amounts of serum DNA have been observed in healthy individuals, whereas high concentrations have been described in patients with various malignancies and in those with several benign diseases, such as infections, sepsis, trauma, stroke, and autoimmune diseases, because most of these disorders are associated with increased rates of cell death events, from either apoptosis or necrosis, these mechanisms are considered to be the main sources for circulating DNA. Quantification of the circulating serum DNA was performed by using Accu-Prep Genomic DNA Extraction Kit (Bioneer. USA). (Jin et al., 2012). 


\section{Statistical Analysis}

Statistical analysis was performed using the One-way ANOVA test utilizing SPSS software. The level of significance was P-value $<0.05$.

\section{RESULTS AND DISCUSSION}

\section{Serum concentration of CEA in colon cancer patients}

Table 1: Serum CEA concentrations in colon cancer patients with different Dukes stage of the disease compared with control

\begin{tabular}{|c|c|c|c|c|c|}
\hline \multirow{2}{*}{$\begin{array}{c}\text { CEA } \\
(\mathbf{n g} / \mathbf{m l})\end{array}$} & \multicolumn{4}{|c|}{ Dukes Stage M \pm SD } & Control \\
\cline { 2 - 6 } & Dukes A & Dukes B & Dukes C & Dukes D & M \pm SD \\
\hline Male & $4.1 \pm 1.64$ & $5.23 \pm 1.8$ & $30.5 \pm 12.7$ & $28.6 \pm 12.65$ & $2.84 \pm 1.09$ \\
\hline Female & $3.8 \pm 1.8$ & $4.8 \pm 2.2$ & $28.2 \pm 12.6$ & $27 \pm 11.2$ & $2.76 \pm 1.09$ \\
\hline Total & $4.0 \pm 1.6$ & $5.07 \pm 1.90$ & $29.45 \pm 12.6^{*}$ & $27.9 \pm 11.7 *$ & $2.9 \pm 1.06$ \\
\hline
\end{tabular}

$(*)$ : Statistically significant differences at $(\mathrm{p}<0.05)$ with control.

The results of the serum CEA concentrations in colon cancer patients with different Dukes stage of the disease compared with control as shown in Table (1) reveled a significant increase at probability $(\mathrm{p}<0.05)$ in CEA Level in stages $\mathrm{C}$ and $\mathrm{D}$ which were, $(29.45 \pm 12.6) \mathrm{ng} / \mathrm{ml},(27.9 \pm 11.7) \mathrm{ng} / \mathrm{ml}$ respectively compared with control group $(2.8 \pm 1.06) \mathrm{ng} / \mathrm{ml}$. while there were no significant difference in serum CEA Level in stages A and B (4.04 \pm 1.6$) \mathrm{ng} / \mathrm{ml},(5.07 \pm 1.90) \mathrm{ng} / \mathrm{ml}$ respectively compared with control groups. These results had been accepted with several other researches such as (Polat et al., 2014) who indicate that serum CEA levels were significantly higher in stages $C$ and D than in stage A. (Ding et al., 2014) reported that the mean of serum's CEA level were higher in dukes stage C of tumor than stage B or A. (Eleftheriadis et al., 2009) found a low sensitivity associated with serum CEA assays in the early stage detection of colorectal cancers. While (Ding et al., 2014) showed that CEA level can be different between Duke stage A and C, C and B, but not between A and B. (Al-bayatti,and jasim 2009) indicate that the elevation of CEA level occur only in patients with advanced stages in colon cancer.

\section{Serum Concentration of C19-9 in Colon Cancer Patients}

Table 2: Serum CA 19-9 concentrations in colon cancer patients with different Dukes stage of the disease compared with control

\begin{tabular}{|c|c|c|c|c|c|}
\hline \multirow{2}{*}{ C19-9 (ng/ml) } & \multicolumn{3}{|c|}{ Dukes Stage M \pm SD } & Control \\
\cline { 2 - 6 } & Dukes A & Dukes B & Dukes C & Dukes D & M \pm SD \\
\hline Male & $11.4 \pm 2.32$ & $55.5 \pm 5$ & $108.4 \pm 7.4$ & $92 \pm 7.1$ & $7.2 \pm 1.54$ \\
\hline Female & $10.02 \pm 1.78$ & $54.3 \pm 4.9$ & $106 \pm 9.2$ & $91 \pm 6.01$ & $7.1 \pm 1.87$ \\
\hline Total & $10.9 \pm 2.18$ & $55.08 \pm 4.87^{*}$ & $107.3 \pm 8.3^{*}$ & $91.6 \pm 6.8^{*}$ & $7.2 \pm 1.68$ \\
\hline
\end{tabular}

$(*)$ : Statistically significant differences at $(\mathrm{p}<0.05)$ with control.

Results in (Table 2) revealed statistically significant increase at $(\mathrm{P}<0.05)$ in the mean values of the serum's CA19-9 Level in patients with stages (B,C) and (D) $(55.08 \pm 4.8) \mathrm{U} / \mathrm{ml},(107.3 \pm 8.3) \mathrm{U} / \mathrm{ml}$ and $(91.6 \pm 6.8) \mathrm{U} / \mathrm{ml}$ respectively compared with controls $(7.2 \pm 1.68) \mathrm{U} / \mathrm{ml}$, whereas no significant variation in patients with stage (A) serum's CA19-9 $(2.18 \pm 10.9) \mathrm{U} / \mathrm{ml}$ compared with control group (7.2 \pm 1.7$) \mathrm{U} / \mathrm{ml}$. 
These results indicate that CA19-9 concentration is significantly elevated in patients with metastatic disease and with increasing the degree of dysplasia or with the size of the lesion. This will agrees with the reports of (Pavai and Yap, 2003) who observed that CA19-9 was very high only in patients with advanced stages of colorectal carcinoma, and (Partyka, 2014) that reported increased serum CA19-9 Level in 21-67\% of advanced colon cancer patients (Hyeon et al., 2013), indicates that metastases showed a stronger expression of CA 19-9 than primary tumors and showed a lower expression in Dukes' A and B tumors than in more advanced stages. The values of CA19-9 in tissues are highest than values in the patients sera with the same type of cancer (Kajiwara et al., 2005). This is an indicator that the cancer cells produce the antigen CA19-9 and release it to the blood (Al-dujaili et al., 2009). Some of the antigen could be corrected with the stage and grade of tumor. The synthesis of CA 19-9 in carcinoma cells is believed to be as a consequence of the activation of specific glycosyl transferase, which is suppressed in normal cells. A gradual increase in the amount of tissue CA19-9 was found in colon and rectum during neoplastic transformation and progression (Kannagi, 2006).

\section{Activity of some Marker Enzymes in Serum of Colon Cancer Patients Serum Alkaline Sphingomyelinase (alk-SMase). Activity in colon cancer patients}

\section{Table 3: Serum sphingomyelinase activity in different Dukes stages of colon cancer patients compared with control}

\begin{tabular}{|c|c|c|c|c|c|}
\hline \multirow{2}{*}{$\begin{array}{r}\text { Alk-SMase } \\
(\mathrm{U} / \mathrm{L})\end{array}$} & \multicolumn{4}{|c|}{ Dukes Stage $\mathrm{M} \pm \mathrm{SD}$} & \multirow{2}{*}{$\begin{array}{l}\text { Control } \\
\mathrm{M} \pm \mathrm{SD}\end{array}$} \\
\hline & Dukes A & Dukes B & Dukes $\mathrm{C}$ & Dukes D & \\
\hline Male & $82.52 \pm 7.2$ & $79.73 \pm 6.2$ & $75.33 \pm 4.91$ & $71.25 \pm 5.02$ & $117.97 \pm 6.88$ \\
\hline Female & $81.6 \pm 7.1$ & $79.5 \pm 5.5$ & $75.56 \pm 3.34$ & $71.66 \pm 5.64$ & $116.24 \pm 5.64$ \\
\hline Total & $82.21 \pm 6.95 *$ & $79.66 \pm 5.81 *$ & $75.44 \pm 4.22 *$ & $71.44 \pm 5.19 *$ & $117.10 \pm 6.25$ \\
\hline
\end{tabular}

$(*)$ : Statistically significant differences at $(\mathrm{p}<0.05)$ with control.

Serum alk-SMase activities related to Dukes stage of colon cancer were shown to be significantly lower in colon cancer patients compared with healthy control, as (Table 3) revealed that. Serum, alkSMase activities was found to be significantly reduced in the early stages A, B stages which were $(82.21+6.95) \mathrm{U} / \mathrm{L}$ and $(79.66+5.81) \mathrm{U} / \mathrm{L}$ respectively compared with healthy $(117.10+6.25) \mathrm{U} / \mathrm{L})$. In addition reduced serum, alk-SMase activities was shown in advanced and metastasis stages $\mathrm{C}, \mathrm{D}$ which were (75.44 \pm 5.19$)$ and (71.44 \pm 5.19$) \mathrm{U} / \mathrm{L}$ respectively compared with healthy $(117.10+6.25) \mathrm{U} / \mathrm{L})$, this agrees with the reports of (Hertervig et al., 1997), who found that, alk-SMase activity preferentially decreases in human colorectal carcinoma, suggesting a regulatory role of the enzyme in colon mucosa cell proliferation. In addition (Hertervig1 et al., 1999) showed that the analysis of, alk-SMase activity in intestinal biopsies from control and colorectal adenocarcinoma patients showed a significant decrease between the enzyme activity in tumor samples and controls with a mean reduction of $90 \%$. It is important to recognize that sphingomyelin pathway is considered as one of the most important intracellular mechanism in regulating cell-growth, differentiation, and apoptosis (Condorelli et al., 1999). The results in (Table 3) also shows that no statistically significant difference was found between Dukes' stages B, C, and D, this agrees with the results of (Marzio et al., 2013) which concluded that, alk-SMase was significantly decreased in tumor line intestinal mucosa of patients compared with controls in dependently of Dukes' stage and tumor differentiation grade. 
Colon Cancer Early Detection by some...........

Serum Cyclooxygenase-2 (COX2) (EC1.14.99.1), activity in colon cancer patients

Table 4: Serum COX2 activity in different Dukes stages of colon cancer patients compared with control

\begin{tabular}{|c|c|c|c|c|c|}
\hline \multirow{2}{*}{$\begin{array}{c}\text { COX2 } \\
(\mathbf{U} / \mathbf{L})\end{array}$} & \multicolumn{4}{|c|}{ Dukes Stage M \pm SD } & Control \\
\cline { 2 - 5 } & Dukes A & Dukes B & Dukes C & Dukes D & M \pm SD \\
\hline Male & $27.24 \pm 1.6$ & $28.6 \pm 1.3$ & $30.1 \pm 2.7$ & $27.04 \pm 1.6$ & $12.07 \pm 1.09$ \\
\hline Female & $25.9 \pm 2.2$ & $27.3 \pm 1.8$ & $30.2 \pm 2.04$ & $27.5 \pm 1.3$ & $12.78 \pm 2.02$ \\
\hline Total & $26.77 \pm 1.91^{*}$ & $28.05 \pm 1.60^{*}$ & $30.18 \pm 2.42^{*}$ & $27.26 \pm 1.56^{*}$ & $12.43 \pm 1.65$ \\
\hline
\end{tabular}

(*): Statistically significant differences at $(\mathrm{p}<0.05)$ with control.

The mean of COX2 activity was found to be significantly increased in serum of malignant colon cancer in comparison to healthy control serum as (Table 4) revealed. Serum COX2 activities in early stages A, B, $(26.77 \pm 1.91) \mathrm{U} / \mathrm{L},(28.05 \pm 1.60) \mathrm{U} / \mathrm{L}$ respectively were significantly increased compared with healthy control $(12.43+1.65) \mathrm{U} / \mathrm{L}$. In addition significantly increased in mean activity of COX2 was shown in advanced and metastasis stages C, D which were (30.18 \pm 2.42$)$ U/L and (27.26 \pm 1.56$)$ $\mathrm{U} / \mathrm{L}$ respectively compared with healthy $(12.57+1.68) \mathrm{U} / \mathrm{L}$, the results was similar to (Singh et al., 2011) who reported that the serum COX-2 was found to be significantly $(\mathrm{P}>0.0001)$ elevate in breast and oral cancer patients compare to the normal control. However, the results in (Table 4) shows the relationship between COX2 activity levels and tumor stages in patients with advanced stage (C) showed higher COX2 activity compared to those with early stage (A, B) which in agreement with (Chan et al., 2007) who reported that gastric cancer and colorectal cancer in patients with advanced serum COX-2 levels were significantly higher. In addition the differences are also further in patients with stage D showed lower activity levels when compared with stage B and C. These findings support the evidence that Aspirin that used as a potential therapeutic agent was associated with a risk reduction in patients whose colon tumors expressed higher levels of COX-2. It is noted that patients with stage A, B showed significantly higher activity levels compared to level of CEA. C19-9 tumor marker measured. A blood serum from 30 patients with primary colon cancer which agreement with (Ota et al., 2002) who reported direct genetic evidence that COX-2 plays a key role in the early stage of intestinal polyp-formation. While (Ali-Osman, 1997; Ueno et al., 2000) results were conformable to our results that overexpression of genes for various enzymes was associated with carcinogenesis and with the development of different tumors.. However, in both human and animal models of colorectal cancers COX-2 expression was dramatically increased in malignancies when compared with adjacent normal mucosa (Jankiram and Rao, 2008). COX-2 may prevent apoptosis not only by generating the antiapoptotic products PGE2 and PGI2 but also by removing a pro apoptotic substrate, arachidonic acid (Konturek et al., 2006).

\section{Serum concentration of Arginase, in colon cancer patients}

Table 5: Serum arginase concentrations in different Dukes stages of colon cancer patients compared with control

\begin{tabular}{|c|c|c|c|c|c|}
\hline \multirow{2}{*}{$\begin{array}{c}\text { Arginase } \\
(\mathbf{n g} / \mathbf{m l})\end{array}$} & \multicolumn{4}{|c|}{ 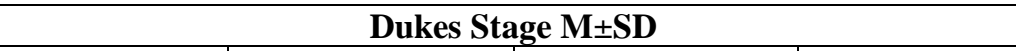 } & \multirow{2}{*}{$\begin{array}{c}\text { Control } \\
\mathbf{M} \pm \text { SD }\end{array}$} \\
\hline & Dukes A & Dukes B & Dukes C & Dukes D & \\
\hline Male & $23.8 \pm 2.7$ & $9.9 \pm 0.96$ & $8.3 \pm 1.4$ & $11.2 \pm 1.27$ & $4.15 \pm 0.34$ \\
\hline Female & $22.4 \pm 1.9$ & $9.8 \pm 0.94$ & $8.24 \pm 1.8$ & $11 \pm 0.97$ & $4.22 \pm 0.36$ \\
\hline Total & $23.3 \pm 2.50 *$ & $9.9 \pm 0.9 *$ & $8.3 \pm 1.4^{*}$ & $11.1 \pm 1.1 *$ & $4.18 \pm 0.35$ \\
\hline
\end{tabular}

$(*)$ :-statistically significant differences at $(\mathrm{p}<0.05)$ with control. 
In the present study, the activity levels of arginase were determined in colon cancer patients serum that revealed significantly increased levels of arginase in colon cancer patients compared to normal subjects $(\mathrm{P}<0.05)$. The mean activity of arginase was found to be significantly higher in the early stages A $(23.3 \pm 2.50),(\mathrm{P}<0.05)$, and in the advanced stages $\mathrm{B}, \mathrm{C}$, and D which was $(9.9 \pm 0.9),(8.3 \pm 1.4)$, $(11.1 \pm 1.1)$ respectively for colon cancer patients in comparison with those of the normal subjects. $(4.18 \pm 0.35)$. (Table 5) shows that there is no significant differences in mean activity of arginase between males and females patients for each stage and control. Due to the elevated arginase activity may be linked to the development of carcinogenesis (Porembska et al., 2003). Leu and Wang 1991 determined that the serum arginase activity had been 2 times higher in the colorectal cancer tissues in colorectal cancer patients when compared to normal mucosal tissues. In addition it has been shown that the over-expression of genes for various enzymes is associated with carcinogenesis and with the development of different tumors (Ali-Osman et al., 1997; Ueno et al., 2000).

The present data are in agreement with previous studies (Leu and Wang, 1991; Porembska et al., 2002) who reported that serum arginase activity levels in patients with colon cancer significantly higher than those found in control subjects.

Table 6: Comparison between patients in stage A colon cancer and control

\begin{tabular}{|c|c|c|}
\hline \multirow{2}{*}{ Parameters } & \multicolumn{2}{|c|}{ Men \pm SD } \\
\cline { 2 - 3 } & Duke stage A & Control \\
\hline CEA ng/ml & $4.04 \pm 1.6$ & $2.8 \pm 1.06$ \\
\hline CA19-9 ng/ml & $10.9 \pm 2.18$ & $7.2 \pm 1.68$ \\
\hline Alk-SMase U/L & $82.21 \pm 6.95^{*}$ & $117.10 \pm 6.25$ \\
\hline COX2 U/L & $26.77 \pm 1.91^{*}$ & $12.43 \pm 1.65$ \\
\hline Arginase $\mathrm{ng} / \mathrm{ml}$ & $23.3 \pm 2.50^{*}$ & $4.17 \pm 0.35$ \\
\hline
\end{tabular}

$(*)$ : Statistically significant differences at $(\mathrm{p}<0.05)$ with control.

The statistical analysis of data listed in (Table 6) show that there was significant difference $(\mathrm{P}<0.05)$ of enzymatic activity for serum) Cyclooxygenase-2, and Arginase) which significantly increase $(26.77 \mathrm{U} / \mathrm{L} \pm 1.91,23.3 \pm 2.50 \mathrm{ng} / \mathrm{ml})$ respectively for patients with early stage A colon cancer compared with controls $(12.57+1.65 \mathrm{U} / \mathrm{L}, 4.18 \pm 0.34 \mathrm{ng} / \mathrm{ml})$ whereas statistical analysis shows non significant increase $(\mathrm{P}<0.05)$ with the levels of CEA and $\mathrm{C} 19-9$ tumor marker $(4.04 \pm 1.6 \mathrm{ng} / \mathrm{mL}$, $10.9 \pm 2.1 \mathrm{U} / \mathrm{ml})$ respectively compared with controls $(2.8 \pm 1.06 \mathrm{ng} / \mathrm{mL}, 7.2 \pm 1.7 \mathrm{U} / \mathrm{ml})$ measured in stage A revealed that (Cyclooxygenase-2 and Arginase) may plays a key role in the early stage of intestinal polypformation.

This study also include the measurement of the enzymatic activity of serum alkaline sphingomyelinase which was significantly decreased $(\mathrm{P}<0.05)$ in colon cancer patients $(82.21 \pm 6.95$ $\mathrm{U} / \mathrm{L})$ in stage A compared with controls (117.10 $\pm 6.25 \mathrm{U} / \mathrm{L})$ and this decrease was independent of Dukes stage, thus strengthening the hypothesized validity of this assay to be used as serum test for the early detection of colonic neoplasia.

\section{Free DNA of Colon Cancer Patients}

The results of this study provide evidence of an increased amount of tumor circulating DNA in the serum of colon cancer patients when compared with normal controls, statistical significant differences in free DNA levels were achieved in all colon cancer's patient with different stages when compared with normal controls as shown in (Table 7). Table (7) Serum Free DNA of colon cancer patients (male and female) with different duke stages disease compared with Control. 
Table 7: Serum Free DNA of colon cancer patients (male and female) with different duke stages disease compared with Control

\begin{tabular}{|c|c|c|c|c|c|}
\hline \multirow{2}{*}{$\begin{array}{c}\text { Free DNA } \\
(\mathbf{n g} / \boldsymbol{\mu} \mathbf{)})\end{array}$} & \multicolumn{4}{|c|}{ Dukes Stage M \pm SD } & \multirow{2}{*}{$\begin{array}{c}\text { Control } \\
\text { M } \pm \text { SD }\end{array}$} \\
\cline { 2 - 5 } & Dukes A & Dukes B & Dukes C & Dukes D & $18.8 \pm 7.7$ \\
\hline Male & $49 \pm 16.8$ & $42.5 \pm 18.1$ & $47 \pm 13.3$ & $58.4 \pm 15.1$ & $19.9 \pm 6.0$ \\
\hline Female & $46.9 \pm 12.6$ & $46.3 \pm 7.87$ & $49.2 \pm 33.2$ & $54.3 \pm 20.6$ & $19.8 \pm 6.9$ \\
\hline Total & $48.1 \pm 15.2$ & $43.9 \pm 15.1^{*}$ & $48.1 \pm 24.7$ & $56.7 \pm 17.4^{*}$ & \\
\hline
\end{tabular}

(*): Statistically significant differences at $(\mathrm{p}<0.05)$ with control.

The mean concentrations $(\mathrm{M} \pm \mathrm{SD})$ of serum's free DNA in patients with stage $\mathrm{A}, \mathrm{B}, \mathrm{C}$ and $\mathrm{D}$ in colon cancer patients were $(48.1 \pm 15.2 \mathrm{ng} / \mu \mathrm{L}), \quad(43.9 \pm 15.1 \mathrm{ng} / \mu \mathrm{L}), \quad(48.1 \pm 24.7 \mathrm{ng} / \mu \mathrm{L})$, and $(56.7 \pm 17.4 \mathrm{ng} / \mu \mathrm{L})$ respectively, which were statistically significant different at $(\mathrm{P}<0.05)$, as highly significant at stage $\mathrm{D}(\mathrm{P}=0.0007)$ than healthy control $(19.8 \pm 6.9 \mathrm{ng} / \mu \mathrm{L})$, while no statistically significant differences between male and female in all patients with different stages of disease and healthy control.

In addition, the mean concentration and purity of mass tissues and serum's extracted DNA had been revealed in (Table 8).

Table 8: Concentration, purity and protein contamination of DNA

\begin{tabular}{|c|c|c|c|}
\hline DNA & $\begin{array}{c}\text { Normal Tissue } \\
\text { Mean } \pm \text { SD }\end{array}$ & $\begin{array}{c}\text { Mass Tissue } \\
\text { Mean } \pm \text { SD }\end{array}$ & $\begin{array}{c}\text { Derum } \\
\text { Mean } \pm \text { SD }\end{array}$ \\
\hline $\begin{array}{c}\text { Concentration Free DNA } \\
(\mathrm{ng} / \mu \mathrm{l})\end{array}$ & $331.6 \pm 90.6$ & $301.6 \pm 94.8$ & $56.75 \pm 17.4$ \\
\hline $\mathrm{A} 260 / \mathrm{A} 280$ & $2.1 \pm 0.44$ & $2.03 \pm 0.52$ & $2.0 \pm 0.37$ \\
\hline $\mathrm{A} 260 / \mathrm{A} 230$ & $0.16 \pm 0.22$ & $0.15 \pm 0.22$ & $0.050 \pm 0.017$ \\
\hline
\end{tabular}

In various pathologic conditions, qualitative and quantitative changes in circulating DNA have been shown. Only small amounts of serum DNA have been observed in healthy individuals, whereas high concentrations have been described in patients with various malignancies and in those with several benign diseases, such as infections, sepsis, trauma, stroke, and autoimmune diseases (Holdenrieder et al., 2005).

Because most of these disorders were associated with increased rates of cell death events, from either apoptosis or necrosis, these mechanisms were considered to be the main sources for circulating DNA. (Umetani et al., 2006; Lichtenstein et al., 2001). A rise of cell-free DNA levels in blood as a result of cell death may be caused by physiological and pathological processes. Cell-free DNA was supposed to be released into the blood circulation by apoptotic and necrotic cells of the primary tumor early during tumorigenesis or actively freed by living cells. (Schwarzenbach et al., 2013). Free circulating DNA in serum was a promising biomarker of cancer because it contains DNA released from dead tumor cells. A large number of studies have reported higher concentrations of serum free DNA in patients with various types of cancer (Flamini et al., 2006). The results of this study provide evidence of an increased amount of tumor circulating DNA in the serum of colon cancer patients when compared with normal controls and it is an important marker for colon cancer detection and reflected tumor stage, while no statistically significant differences between mean concentration of free DNA in different Duke stage and gender with slightly increased in stage D as shown in (Table 7) these results agree with the results of (Flamini et al., 2006) that observed a higher free DNA levels in the serum of breast cancer's patients compared with those of controls, independently of tumor size and stage. Elevated free DNA concentration in gastrointestinal tract cancer patient's serum seems to correlate with the presence 
of tumor and/or metastatic disease and it was 3- to 24-fold higher than that of plasma's circulating free DNA, there for its a better source for circulating DNA (Thijssen et al., 2002; Jung et al., 2003).

\section{REFERENCES}

Abdallah, A.; Belal, M.; El Bastawisy, A.; Gaafar, R. (2013). Plasma CA19-9 in advanced non-small cell lung cancer. J. Cancer Clinic. Oncology; 2(2), 11-18.

AL-Bayatti, S.N.; Jasim, F. (2009). Colorectal Cancer in a group of Iraqi patients. J. MMJ. 8, 36-39

Al-Dujaili, A.H.; Al-Taei, W.F.; Turky, K.M.; Al-Ubaidi, G.H. (2009). Comparative study of CA19-9 levels as tumor marker in sera and tissues of patients with stomach, colon and rectum cancers. J. Fac. Med. Baghdad., 51(2), 223-226.

Ali-Osman, F.; Brunner, J.M.; Kutluk, T.M.; Hess, K. (1997). Prognostic significance of Glutathione S-Transferase Expression and Subcellular Localization in human Gliomas. Clinical Cancer Research, 3, 2253-2261.

Al-Saadi, N.H.; Al-Daami, N.M.; Hussain, A. (2014). Biochemical bone markers in prostate cancer patients with advanced bone metastasis. J. Kerbala Univ., 12(4), 143-149.

Ash, D.E. (2004). Arginine Metabolism: Enzymology, Nutrition, and Clinical Significance. American Soc. for Nutritional Sci., 4, 22-3166.

Brünner, N.; Haglund, C.; Andersen, M.; Nielsen, H.; Duffy, M. (2006). National academy of clinical biochemistry guidelines for the use of tumor markers in colorectal cancer. J. NACB: Practice Guidelines and Recommendations for Use of.

Campbell, N.C.; Elliott, A.M.; Sharp, L.; Ritchie, L.D.; Cassidy; Little, J. (2001). Rural and urban differences in stage at diagnosis of colorectal and lung cancers. J. Cancer, 84(7), 914-910.

Chan, A.T.; Ogino, S.; Fuchs, C.S. (2007). Aspirin and the risk of colorectal cancerin relation to the expression of COX-2. J. NEngl. Med., 356, 2131-42.

Chan, A.T.; Giovannucci, E.L. (2010). Primary prevention of colorectal cancer. J. Gastroenterology, 138(6), 2029.

Cheng, Y.; Nilsson, A.; Tömquist, E.; Duan, R. (2002). Purification, characterization, and expression of rat intestinal alkaline sphingomyelinase. J. Lipid Res., 43, 316.

Condorelli, F.; Canonico, P.L.; Sortino, M.A. (1999). Distinct effects of ceramide-generating pathways in prostate adenocarcinoma cells. British J. Pharma., 127,75.

Ding, Y.; Xuan, W.; Chen, C.; Chen, Z.; Yang, Z.; Zuo, Y.; Ren, S. (2014). Differences in carcinoembryonic antigen levels between colon and rectal cancer. J. Mol. Clinic. Oncology, 2, 618-622.

Duan, R.; Cheng, Y.; Jo“nsson, B.; Ohlsson, L.; Herbst, A.; Hellstro“m-Westas, L.; Nilsson, A. (2007). Human meconium contains significant amounts of alkaline sphingomyelinase, neutral ceramidase, and sphingolipid metabolites. J. International Pediatric Research, 61(1),61-66.

Duffy, M. J. (2001). Carcinoembryonic antigen as a marker for colorectal cancer is it clinically useful?. J. Clinic. Chem., 47(4), 624-630

Eleftheriadis, N.; Papaloukas, C.; Pistevou-Gompaki, K. (2009). Diagnostic value of serum tumor markers in asymptomatic individuals. J. BUON., 14(4), 707-10

Elshimali, Y.I.; Khaddour, H.; Sarkissyan, M.; Wu, Y.; Vadgama, J.V. (2013). The clinical utilization of circulating cell free dna (ccfdna) in blood of cancer patients. Int. J. Mol. Sci., 14, 1892518958. 
Flamini, E.; Mercatali, L.; Nanni, O.; Calistri, D.; Nunziatini, R.; Wainer, Z.; Rosetti, P.; Gardini, N.; Lattuneddu, A.; Verdecchia, G.; Amadori, D. (2006). Free DNA and carcinoembryonic antigen serum levels an important combination for diagnosis of colorectal cancer. J. Clin. Cancer Res., 12(23), 6985 -6988.

Hertervig, E.; Nilsson, A.; Björk, J.; Hultkrantz, R.; Duan, R. (1999). Familial adenomatous polyposis is associated with a marked decrease in alkaline sphingomyelinase activity: a key factor to the unrestrained cell proliferation?. British J. Cancer, 81(2), 232-236.

Hertervig, E.; Nilsson, K.; Nyberg, L.; Duan, R. (1997). Alkaline sphingomyelinase activity is decreased in human colorectal carcinoma. J. Cancer, 79(3),449-453

Holdenrieder, S.; Stieber, P.; Chan, L.; Geiger, S.; Kremer, A. Nagel, D.; Dennis, Y. (2005). Cell-free DNA in serum and plasma comparison of ELISA and quantitative PCR. J. Clinic. Chem., 51(8), 1544-1546.

Hyeon, Y.; Son, G.; Joh, Y. (2013). The clinical significance of preoperative serum levels ofcarbohydrate antigen 19-9 in colorectal cancer. J. Koreansurg Soc., 84, 231-237.

Jamshidzadeh, A.; Aminlari, M.; Rasekh, H. (2001). Rhodanese and arginase activity in normal and cancerous tissues of human breast, esophagus, stomach and lung. J. Arch. Irn. Med., 4(2), 8892.

Janakiram, N.B.; Rao, C.V. (2008). Molecular markers and targets for colorectal cancer prevention. $J$. Acta. Pharmacol. Sin.6 29(1), 1-20.

Jin, D.; Xie, S.; Mo, Z.; Liang, Y.; Guo, B.; Huang, G.; Dong, J. (2012). Circulating DNA-important biomarker of cancer. J. Mol. Biomarkers Diagn, 5, 2-7.

Jung, M.; Klotzek, S.; Lewandowski, M.; Fleischhacker, M.; Jung, K. (2003). Changes in concentration of DNA in serum and plasma during storage of blood samples. J. Clin. Chem., 49(6), 10281029.

Kajiwara, H.; Yasuda, M.; Kumaki, N.; Shibayama, T.; Osamura, Y. (2005). Expression of carbohydrate antigens) SSEA-1, sialyl-Lewis X, DU-PAN-2 and CA19-9) and E-selectin in urothelial carcinoma of the renal pelvis, ureter, and urinary bladder. Tokai. J. Exp. Clin. Med., 30(3), 177-82.

Kannagi, R. (2006). Carbohydrate antigen sialyl lewis a - Its pathophysiological significance and induction mechanism in cancer progression. Chang Gung Med. J., 30(3), 464-8681.

Kocna, P.; Fric, P.; Zavoral, M.; Pelech, T. (1996). Arginase activity determination A marker of large bowel mucosa proliferation. Eur. J. CHn. Chem. Clin. Biochem., 34, 619-623.

Konturek, P. C.; Rembiasz, K.; Burnat, G.; Konturek, S. J.; Tusinela, M.; Bielansk, W.; Rehfeld, J.; Karcz, D.; Hahn, E. (2006). Effects of Cyclooxygenase -2 Inhibition on serum and tumor Gastrins and expression of apoptosis-related proteins in colorectalcancer. J. Digestive Diseases and Sci., 51(4), 779-787.

Leu, S.; Wang, S. (1991). Clinical significance of Arginase in colorectal cancer. J. Cancer, 70(4), 733736.

Lichtenstein, A.V.; Melkonyan, H.S.; Tomei, L.D.; Umansky, S.R. (2001). Circulating nuclic acid and apoptosis. J. Ann. N Y Acad. Sci., 945, 239-49.

Mahmoud, A.A.; El-Said, S.E.; Mandour, M.A.; Zakhary, M.M.; Maximous, D.W. (2009). Arginase activity in Brest Cancer: is it significant biomarker?. J. Bull. Pharm. Sci., Assiut University, 32(2), 241-247. 
Marzio, L.; Leo, A.; Cinque, B.; Fanini, D.; Agnifili, A.; Berloco, P.; Linsalata, M.; Lorusso, D.; Barone, M.; Simone, C.; Cifone, M. (2013). Detection of Alkaline sphingomyelinase activity in human stool: proposed role as a new diagnosticand prognostic marker of colorectal cancer. J. American Assoc. Cancer Res., 14, 856-862.

Mihajlovic-Bozic, V. (2004). Risk factors for colorectal cancer. Institute of Oncology Sremska Kamenica, Serbia and Montenegro, 12(1), 45-49.

Ota, S.; Bamba, H.; Kato, A.; Kawamoto, C.; Yoshida, Y.; Fujiwara, K. (2002). Review article COX-2, prostanoids and colon cancer. J. Aliment. Pharmacol. Ther., 16(2), 102-106.

Partyka, R. (2014). Role of Tumour markers in diagnosis and follow up of colorectal cancer-potential for future research. J. Anticancer Res., 29, 4202-4208.

Pavai, S.; Yap, S.V. (2003). The clinical significance of elevated levels of serum CA 19.9. Med. J. Malaysia., 58(5), 667-672.

Pavai, S.; Yap, S.V. (2003). Tumor Markers in The Clinic Colorectal Cancer, The Clinical Significance of Elevated Levels of Serum CA 19.9". Med. J. Malaysia., 3:2-18. 58(5), 667-672.

Polat, E.; Duman, U.; Duman, M.; Atici, A.; Reyhan, E.; Dalgic, T. Bostanci, E.; Yol, S. (2014). Diagnostic value of preoperative serum carcinoembryonic antigen and carbohydrate antigen 19-9 in colorectal cancer. J. Current Oncology، 21(1), 1-7.

Porembska, Z.; Luboiński, G.; Chrzanowska, A.; Mielczarek, M.; Magnuska, J.; Barańczyk-Kuźma, A. (2003). Arginase in patients with breast cancer. Clin. Chim. Acta., 328(1), 105-11.

Porembska, Z.; Skwarek, A.; Mielczarek, M.; czyk-Kuz'ma A. (2002). Serum arginase activity in postsurgical monitoring of patients with colorectal carcinoma. J. Cancer., 94(11), 2930-2934.

Schwarzenbach, H. (2013). Circulating nucleic acids as biomarkers in breast Cancer. Schwarzenbach Breast Cancer Research, 15(211), 1-9.

Singh, A.K.; Kumar, R.; Parsad, R.; Dey, S. (2011). COX-2 as a serum marker and therapeutic agent for cancer. J. Natural Sci. Biology and Medicine, 2(2), 142.

Thijssen, M.A.; Swinkels, D.W.; Ruers, T.J.; deKok, J.B. (2002). Difference between free circulating plasma and serum DNA in patients with colorectal liver metastases. Anticancer Res., 22(1), 421-425.

Ueno, H.; Mochizuki, H.; Hatsuse, K.; Hase, K.; Yamamoto, T. (2000). Indicators for treatment Strategies of colorectal liver Metastases. Annals of surgery, 231(1), 59-66.

Umetani, N.; Hiramatsu, S.; Hoon, D. (2006). Higher amount of free circulating DNA in serum than in plasma is not mainly caused by contaminated extraneous DNA during separation. Ann. N. Y. Acad. Sci., 1075, 299-307.

Urade, M. (2008). Cyclooxygenase (COX)-2 as a potent molecular target for prevention and therapy of oral cancer. Japanese Dental Sci. Review, 44, 57-65.

Wu, J.; Liu, F.; Nilsson, A.; Duan, R. (2004). Pancreatic trypsin cleaves intestinal alkaline sphingomyelinase from mucosa and enhances the sphingomyelinase activity. American $J$. Physiol. Gastrointest. Liver Physiol., 287, 967-973.

Wu, J.; Nilsson, A.; J “onsson, B.; Stenstad, H.; Agace, W.; Cheng Y.; Duanr, R. (2006). Intestinal alkaline sphingomyelinase hydrolyses and inactivates platelet-activating factor by a phospholipase C activity. Biochem. J., 394, 299-308. 